\title{
Conversion of Sandy Tailing from Banded Iron Formation Exploitation into Glass-ceramic Materials
}

\author{
Valéria Alves Rodrigues de Melo ${ }^{\mathrm{a}}$, Fernando Soares Lameiras ${ }^{\mathrm{a}}$, Evandro Tolentino ${ }^{\mathrm{b} *}$ \\ ${ }^{a}$ Centro de Desenvolvimento de Tecnologia Nuclear - CDTN, \\ Comissão Nacional de Energia Nuclear - CNEN, Universidade Federal de Minas Gerais - UFMG, \\ Rua Professor Mário Werneck, s/n, CEP 31270-901, Belo Horizonte, MG, Brazil \\ ${ }^{b}$ Centro Federal de Educação Tecnológica de Minas Gerais - CEFET-MG, \\ Av. Amazonas, 1193, Campus VII, Vale Verde, CEP 35183-006, Timóteo, MG, Brazil
}

Received: January 11, 2011; Revised: November 2, 2011

\begin{abstract}
Glass-ceramic materials made of $40.0 \mathrm{wt}$ (\%) of sandy tailing from banded iron formation exploitation and $60 \mathrm{wt}$. (\%) of slag from steelwork were analyzed. Vitrification was obtained by heating the batch samples up to $1400^{\circ} \mathrm{C}$ for 1 hour and quenching the melt on a stainless steel plate. Devitrification was obtained by heat-treating the as-quenched glass samples in isothermal conditions at 750 and $1000{ }^{\circ} \mathrm{C}$ for 2 hours. FTIR spectroscopy analysis on the devitrified samples indicates a peak shift towards higher wave number with respect to the as-quenched glass because of the crystallization. XRD analysis revealed the presence of crystalline diopside $\mathrm{CaMgSi}_{2} \mathrm{O}_{6}$ as the major phase in the glass samples isothermally heat-treated at $1000^{\circ} \mathrm{C}$. Results also indicated that the devitrification at $1000{ }^{\circ} \mathrm{C}$ and an incipient devitrification at $750{ }^{\circ} \mathrm{C}$ resulted into harder glass-ceramic materials.
\end{abstract}

Keywords: glass-ceramic, sandy tailing, steelwork slag

\section{Introduction}

The iron ore exploitation established in the State of Minas Gerais, Brazil, produces huge amounts of residues. These residues are neither toxic nor hazardous and can be used as raw materials in several industrial segments. Much of this ore is banded iron formations (also known as banded ironstone formations or BIFs). BIFs are chemically precipitated sedimentary rocks, with structures consisting of repeated thin layers (millimeter to centimeter scale) of black to dark gray colored iron oxides, either magnetite or hematite, alternating with bands of red, yellow, or cream colored layers of chert or jasper. They are exploited in the Quadrilátero Ferrífero (a region in the center of Minas Gerais) to obtain a pelletized iron ore concentrate, that can be processed by the steel industry. About half of the BIFs are transformed in pellets. The remaining part is disposed of in dams as tailings and slimes with high cost and many environmental concerns.

For instance, the Samarco Miming Company has generated in $200910,353,929$ day metric tons of sandy tailings and 3,359,241 day metric tons of slime in the city of Mariana, Minas Gerais. A similar situation can be found in other municipalities in the Quadrilátero Ferrífero.

The purpose of this paper is to report a study to obtain a glass-ceramic material made with sandy tailing. Steelwork slag from a Company close to the iron mines of Quadrilátero Ferrífero was selected as flux.

\section{Literature Review}

Vitrification is a well-established technique for converting wastes into glasses of remarkable chemical stability. Glass

*e-mail: tolentino.evandro@gmail.com can be defined as a non-crystalline solid exhibiting the phenomenon of glass transition. The corresponding physical state is called the vitreous state. This definition does not impose any restrictions relative to the manner in which the vitreous material is obtained. Certain thin films (Si, Ge) that always crystallize at elevated temperatures are not considered to be glasses, and it is appropriate to reserve for them the term amorphous ${ }^{1}$. A relatively inert glass is produced by vitrification at temperatures above $1200-1300{ }^{\circ} \mathrm{C}^{[2]}$. The vitrification process usually results in a large waste volume reduction, with evident benefits in terms of storage or dumping. It comprises the co-melting of solid waste with appropriate vitrifying and melting agents. The toxic elements and/or chemical substances can either participate in the formation of the glass network or be captured in the form of precipitates ${ }^{3}$. However, it must be pointed out that vitrification is generally energy and capital intensive. The economic disadvantage of vitrification may be counterbalanced by the conversion of wastes into marketable glass products. The most important example of this approach, since the 1960's, is represented by the manufacture of glassceramic materials ${ }^{4}$.

Glass-ceramic materials are a class of materials obtained by controlled crystallization of glass. The appropriate glasses are subjected to carefully controlled heat-treatment, which cause the nucleation and growth of crystalline phases. The process is designed to convert the initial vitreous phase into a polycrystalline material ${ }^{1}$. Whether a crystalline or glassy phase is formed depends on many parameters such as constituents, rate of cooling, and the presence or absence of nucleating agents. The entire nucleation mechanism in 
glass-ceramic materials represents combined homogeneousheterogeneous nucleation ${ }^{5}$. The research activities and efforts carried out by several authors in treating industrial wastes, i.e. goethite, wastes resulted from the hydrometallurgy of zinc, fly ash from domiciliary, incinerators wastes, coal fly ash, and blast furnace slags, demonstrate the wide possibility of using such wastes to resolve environmental problems and contribute to the efforts for waste regulations and pollution prevention $^{6}$. The production of glass-ceramic materials based on inorganic industrial solid wastes is a promising line of recycling and beneficiation of by-products and waste materials, and has been used very successfully to crystallize important ceramics from the glass phase. Some of these glass-ceramic materials became commercial products and found their applications in the field of abrasion-resistant materials, that is, industrial floor coverings, wall facings, abrasion-resistant linings, and high-temperature insulators ${ }^{7}$. Application of glass-ceramic to make construction and decorative materials is also a common process ${ }^{8,9}$.

\section{Experimental}

\subsection{Materials}

The sandy tailing samples used in this study were obtained from Samarco Mining Company, in Mariana city, Brazil. Before further use in the experimental work, the sandy tailing samples were dried 24 hours at $120{ }^{\circ} \mathrm{C}$ for moisture removal. Reciclos Company, in Timóteo city, Minas Gerais, Brazil, provided the steelwork slag samples. The origin of the Reciclos Company's slag was Aperam Steel Company, from which most of iron was removed. The slag samples were dried at $120{ }^{\circ} \mathrm{C}$ for 24 hours and the dried powder was dry ball-milled and sieved to particles smaller than $0.075 \mathrm{~mm}$ (sieve \#200).

The chemical composition of the sandy tailing and steelwork slag samples was evaluated by X-ray fluorescence (XRF) analysis using SHIMADZU EDX-720 equipment. In order to identify crystalline phases in the samples XRD analysis was performed, using an X-ray Diffractometer RIGAKU-GEIGERFLEX with $\mathrm{CuK} \alpha$ radiation at voltage $40 \mathrm{kV}$ and current $30 \mathrm{~mA}$; scanning speed, $8 \% \mathrm{~min}$; scanning range, $4-80^{\circ}(2 \theta)$. FTIR analysis was applied as well in order to identify crystalline phases in the samples using FTIR ABB Bomen MB 102 equipment.

\subsection{Glass preparation}

The batch composition was prepared by mixing $40.0 \mathrm{wt}$. (\%) of sandy tailing with $60.0 \mathrm{wt}$. (\%) of steelwork slag. The melting was performed by using an electrical tubular laboratory furnace, where $5 \mathrm{~g}$ batches were heated up to $1400{ }^{\circ} \mathrm{C}$ at a rate of $10{ }^{\circ} \mathrm{C} / \mathrm{min}$ in alumina crucibles, and this temperature was maintained for 1 hour. Following this procedure, the melt was quenched by pouring it onto a stainless steel plate at room temperature. Some of the asquenched products were dry ball-milled and sieved to sizes smaller than $0.075 \mathrm{~mm}$.

\subsection{Glass crystallization}

The sieved dry ball-milled glass sample was pressed at $6.4 \mathrm{MPa}$ into a small disk shape, having a diameter of $10 \mathrm{~mm}$ and thickness of $2 \mathrm{~mm}$, without any binder. In order to promote devitrification, the disk shaped bodies were placed in a box-type $\mathrm{SiC}$ furnace and heat-treated for 2 hours in isothermal conditions at 750 and $1000{ }^{\circ} \mathrm{C}$. Some of the heat-treated products were dry ball-milled and sieved to sizes smaller than $0.075 \mathrm{~mm}$.

\subsection{Characterization of as-quenched glass and heat-treated glass samples}

XRD analyses were performed in order to determine the crystalline phases present in the as-quenched glass and heat-treated glass materials. FTIR analyses were also applied to the as-quenched glass and heat-treated glass samples in order to investigate the crystallization process. Only the as-quenched glass sample was subjected to DTA analyses in order to obtain information on the glass transition temperature $\left(\mathrm{T}_{\mathrm{g}}\right)$ and the position of exothermic peaks that correspond to crystal phase separation. The DTA traces were obtained with TA Instruments 2960 SDT equipment, recorded in air atmosphere at a heating rate of $10^{\circ} \mathrm{C} / \mathrm{min}$, and $\mathrm{Al}_{2} \mathrm{O}_{3}$ was used as reference material. All the samples analyzed by XRD, FTIR, and DTA were powdered by dry ball-milling and sieved to sizes smaller than $0.075 \mathrm{~mm}$. The microhardness (HV) measurements were performed on chunked as-quenched and heat-treated glass samples. The chunked samples were embedded in polystyrene resin and the sample surfaces were polished with diamond paste $(6,3$, and $1 \mu \mathrm{m})$. The microhardness of the samples was measured using a Vickers tester (Durimet Leitz). A constant load of $200 \mathrm{~g}$ was applied for 15 seconds and 5 indentations were made on each sample.

\section{Results and Discussion}

\subsection{Sandy tailing samples}

The oxide composition of the dried sandy tailing sample obtained by XRF is given in Table 1. In Figure 1a, the XRD diffractogram of the sandy tailing is reported. The mineralogical characterization of the sandy tailing obtained by XRD revealed that its major components were quartz $\mathrm{SiO}_{2}(>50 \%)$, hematite $\mathrm{Fe}_{2} \mathrm{O}_{3}(<40 \%)$, goethite $\mathrm{FeO} . \mathrm{OH}$ and magnetite $\mathrm{Fe}_{3} \mathrm{O}_{4}(<3 \%)$.

The FTIR spectrum of the sandy tailing is shown in Figure 2a. The band at $1090 \mathrm{~cm}^{-1}$ was assigned to the asymmetric Si-O-Si stretching vibration, the peak at $798 \mathrm{~cm}^{-1}$ was assigned to the symmetric stretching vibration, and the peak at $463 \mathrm{~cm}^{-1}$ was assigned to the asymmetric bending vibration, as proposed by Pisciella \& Pelino ${ }^{10}$. The

Table 1. Chemical composition of the dried sandy tailing from banded formation in weight percentage of the oxides.

\begin{tabular}{cc}
\hline Constitutive oxides & $\begin{array}{c}\text { Chemical composition } \\
\text { (wt. (\%)) }\end{array}$ \\
\hline $\mathrm{SiO}_{2}$ & 84.2 \\
$\mathrm{Fe}_{2} \mathrm{O}_{3}$ & 11.6 \\
$\mathrm{SO}_{3}$ & 1.8 \\
$\mathrm{Al}_{2} \mathrm{O}_{3}$ & 1.6 \\
Ignition loss & 0.8 \\
\hline
\end{tabular}




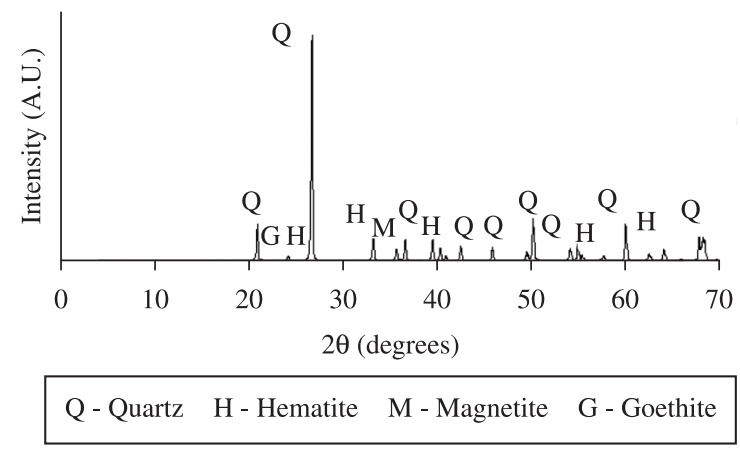

(a)

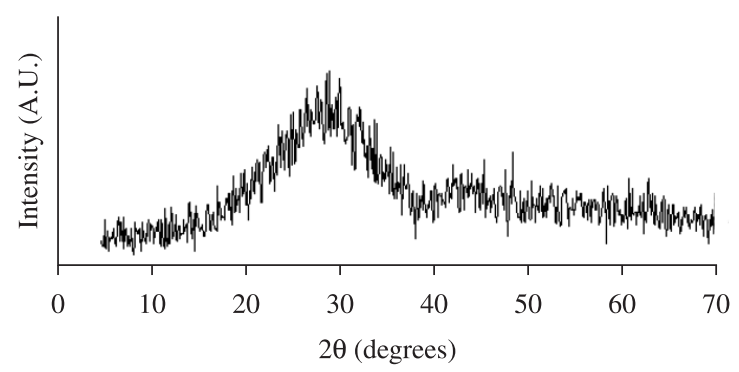

(c)

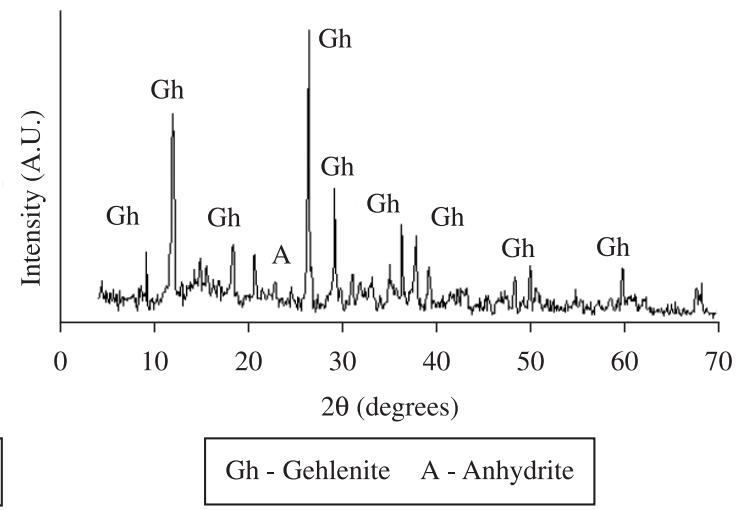

(b)

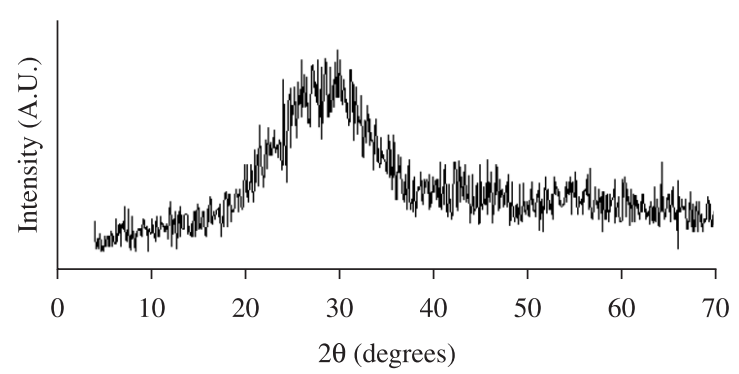

(d)

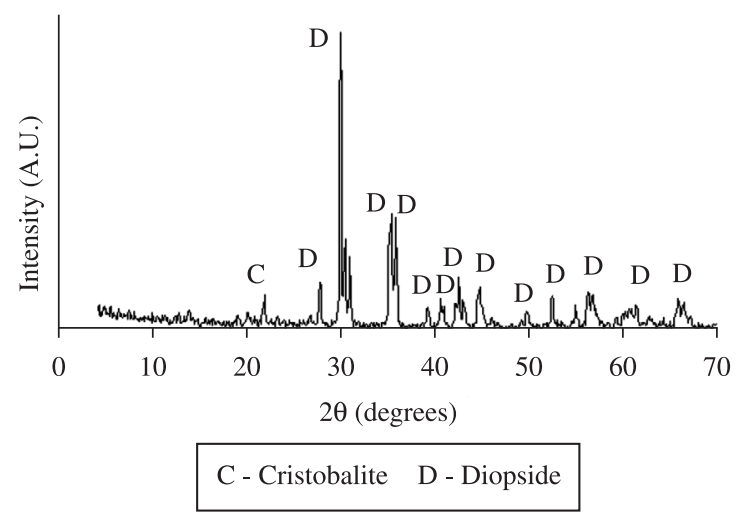

(e)

Figure 1. X-ray diffractograms from: a) sandy tailing, b) steelwork slag, c) as-quenched glass, d) glass heat-treated at $750{ }^{\circ} \mathrm{C}$, and e) glass heat-treated at $1000^{\circ} \mathrm{C}$.

asymmetry observed at 1090 and $463 \mathrm{~cm}^{-1}$ bands is probably due to their superposition on the lower intensity bands related to the $\mathrm{Fe}-\mathrm{O}$ vibration. Band at 1185 and $520 \mathrm{~cm}^{-1}$ are attributed to $\mathrm{Fe}-\mathrm{O}$ vibration ${ }^{11}$.

\subsection{Steelwork slag samples}

The chemical composition of the steelwork slag determined using XRF is shown in Table 2.

In Figure 1b, the XDR diffractogram of the sieved dry ball-milled steelwork slag is presented. The results obtained by XRD analysis for the steelwork slag sample revealed that its major crystalline phase was gehlenite $\mathrm{Ca}_{2} \mathrm{Al}_{2} \mathrm{SiO}_{7}$ $(>95 \%)$; its minor crystalline phase was anhydrite $\mathrm{CaSO}_{4}$ $(<3 \%)$.
In Figure 2b, the FTIR spectrum of the steelwork slag is shown. It shows typical bands at about 1100, 800 and $470 \mathrm{~cm}^{-1}$, and these bands were assigned to the $\mathrm{Si}-\mathrm{O}-\mathrm{Si}$ stretching vibration. The remaining bands were assigned to the $\mathrm{Ca}-\mathrm{O}$ and $\mathrm{Mg}-\mathrm{O}$ vibration.

\subsection{As-quenched glass samples}

Figure 3a shows a digital image of the glass sample just after quenching by pouring out the melt onto a stainless steel plate at room temperature. One can see that the alumina crucible is still heated. Figure $3 \mathrm{~b}$ shows a digital image of the glass sample remaining on the bottom of another alumina crucible after pouring out the melt. One can see that the cooled melt has become a shiny dark brown-colored glass. 


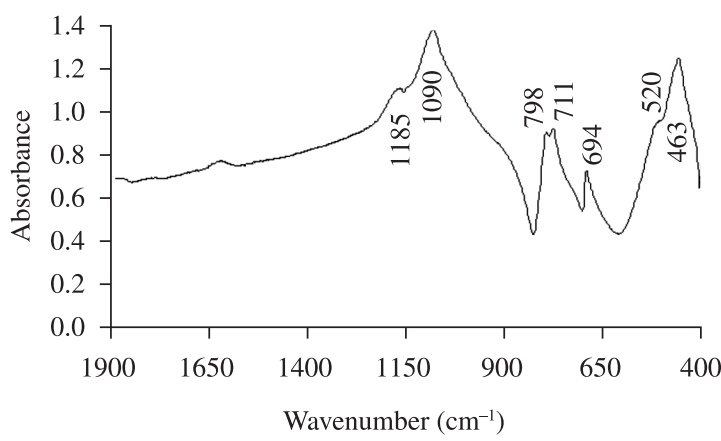

(a)

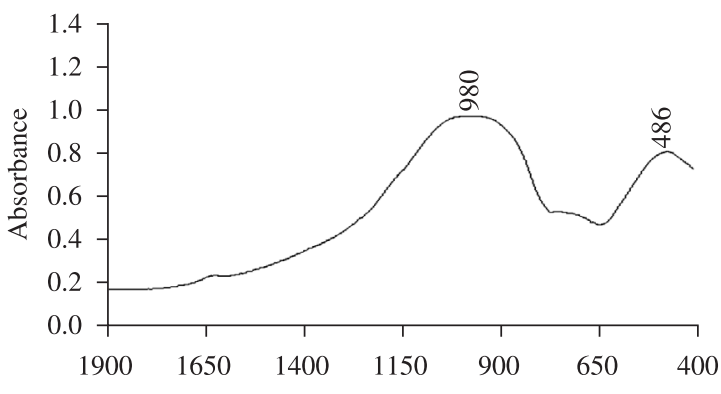

Wavenumber $\left(\mathrm{cm}^{-1}\right)$

(c)

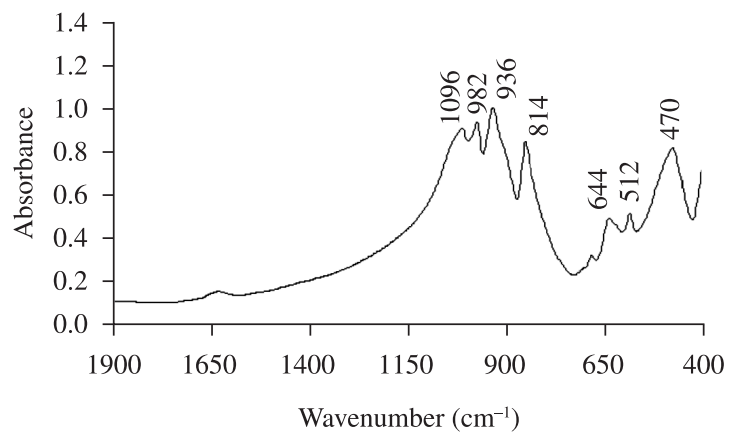

(b)

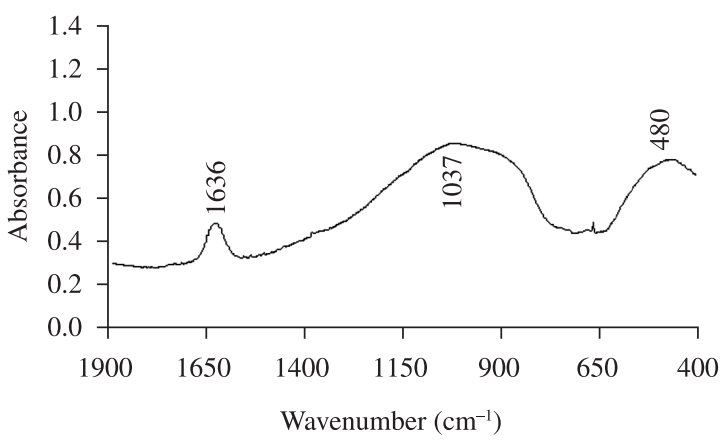

(d)

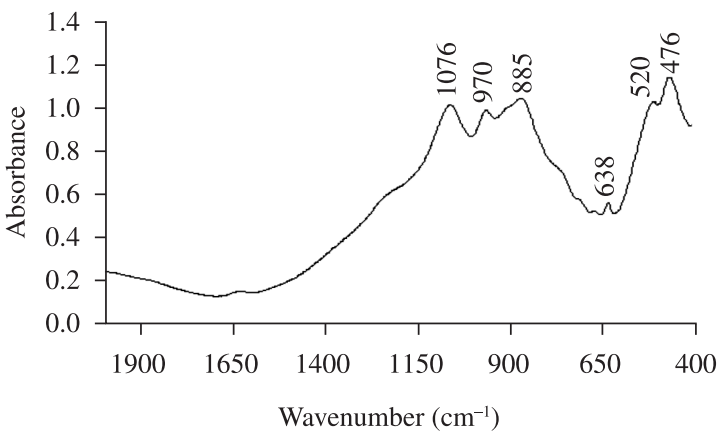

(e)

Figure 2. FTIR spectra from: a) sandy tailing, b) steelwork slag, c) as-quenched glass, d) glass heat-treated at $750{ }^{\circ} \mathrm{C}$, and e) glass heattreated at $1000{ }^{\circ} \mathrm{C}$.

Table 2. Chemical composition of the steelwork slag in weight percentage of the oxides.

\begin{tabular}{cc}
\hline Constitutive oxides & $\begin{array}{c}\text { Chemical composition } \\
\text { (wt. (\%)) }\end{array}$ \\
\hline $\mathrm{CaO}$ & 40.8 \\
$\mathrm{SiO}_{2}$ & 38.4 \\
$\mathrm{MgO}$ & 16.4 \\
$\mathrm{Al}_{2} \mathrm{O}_{3}$ & 2.0 \\
$\mathrm{SO}_{3}$ & 1.3 \\
$\mathrm{Fe}_{2} \mathrm{O}_{3}$ & 0.6 \\
Ignition loss & 0.5 \\
\hline
\end{tabular}

The XRD pattern of the as-quenched glass samples is shown in Figure 1c. The absence of peaks indicates the noncrystalline state of the samples. No significant crystalline phase could be detected in the tested samples.
The FTIR spectrum of the as-quenched glass samples is shown in Figure 2c. The band at $980 \mathrm{~cm}^{-1}$ was assigned to the asymmetric $\mathrm{Si}-\mathrm{O}-\mathrm{Si}$ stretching vibration, and this result possibly indicates a negative shift (towards lower wave number) of the peak at $1100 \mathrm{~cm}^{-1}$ as a result of a decrease in the average $\mathrm{Si}-\mathrm{O}-\mathrm{Si}$ bond angle ${ }^{12}$, since the position of the peak related to the asymmetric stretching vibration is strongly affected by changes in the average $\mathrm{Si}-\mathrm{O}-\mathrm{Si}$ bond angle ${ }^{13}$. Since the band at $1100 \mathrm{~cm}^{-1}$ has been extensively investigated, the presence of wide bands instead of narrow ones as has shown in Figure 2c highlights the structural disorder of the as-quenched glass. It could be that the widening of the bands is due to molecular disorder near the $\mathrm{Si}-\mathrm{O}-\mathrm{Si}$ group. As reported by Bell et al. ${ }^{14}$, the disparity between glass and crystal spectra is due to breaking of interatomic bonds and distortion of individual molecular units. 


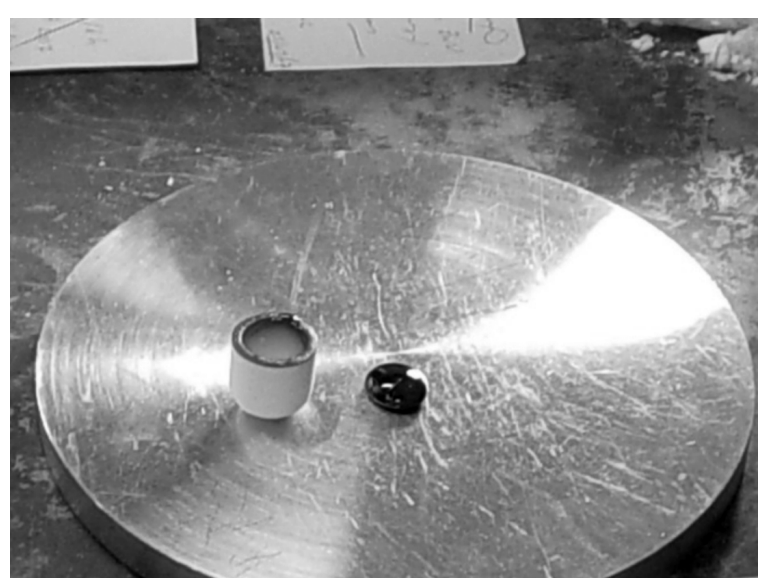

(a)

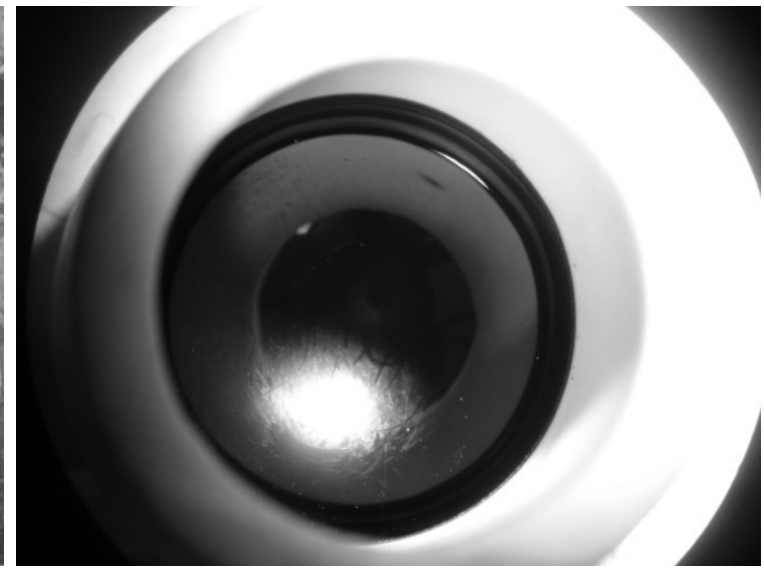

(b)

Figure 3. Digital images of the as-quenched glass: a) Glass sample just after quenching by pouring out the melt on a stainless steel plate at room temperature, b) Shiny dark brown-colored glass remaining on the bottom of another alumina crucible after pouring out the melt.

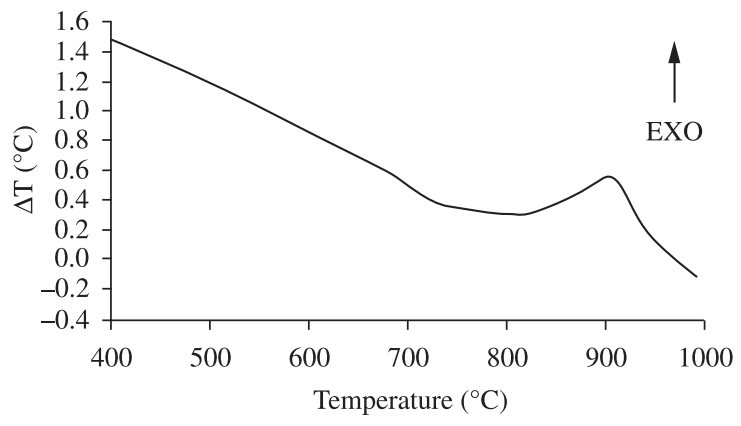

Figure 4. DTA heating curve for the as-quenched glass.

DTA heating curve is depicted in Figure 4. A slope change at $\sim 720{ }^{\circ} \mathrm{C}$ was observed, and it could indicate a glass transition temperature, $\mathrm{T}_{\mathrm{g}}$, according to Francis ${ }^{6}$. A broad exothermic peak was also detected at $\sim 910{ }^{\circ} \mathrm{C}$, and its position would presumably correspond to crystal phase separation. A broad crystallization peak indicates surface crystallization, while a sharp peak signifies bulk crystallization, as proposed by Kavouras et al. ${ }^{9}$. The socalled "glass-ceramic" are materials in which a crystalline phase is nucleated and grown from a glass matrix. Since the powder sample submitted to DTA analysis were dry ballmilled and sieved to $<0.075 \mathrm{~mm}$, it possesses more specific area. Consequently, it could be assumed that the origin of the crystallization is a heterogeneous surface nucleation of the specific crystal phase. In order to transform the glass to a glass-ceramic, two crystallization heat-treatments processes were carried out for 2 hours in isothermal conditions on the as-quenched glass samples: at $750{ }^{\circ} \mathrm{C}$ (just after the glass transition temperature) and $1000^{\circ} \mathrm{C}$ (after the crystal phase separation peak).

The value determined for the Vickers microhardness was $714 \pm 19 \mathrm{HV}(\sim 7 \pm 0.2 \mathrm{GPa})$ for $95 \%$ confidence level (the mean value was $714 \mathrm{HV}$; the standard deviation was $14 \mathrm{HV}$; the n-1 degrees of freedom of all tests were 4). The obtained result is in agreement with literature ${ }^{15}$.

\subsection{Heat-treated glass samples}

The results of XRD analysis on glass samples heattreated at 750 and $1000{ }^{\circ} \mathrm{C}$ are presented in Figure $1 \mathrm{~d}$ and $1 \mathrm{e}$, respectively. One can note that the diffractogram of the glass sample heat-treated at $750{ }^{\circ} \mathrm{C}$, as it is depicted in Figure 1d, is very similar to the pattern depicted in Figure 1c for the as-quenched glass sample. The appearance of the two diffractograms suggests the absence of crystalline phase for both materials. Nevertheless, the XRD pattern of the glass sample heat-treated at $1000{ }^{\circ} \mathrm{C}$ indicated that there is no doubt that crystalline phases coexist, since the non-crystalline phase has practically disappeared. The crystallization produced crystalline diopside $\mathrm{CaMgSi}_{2} \mathrm{O}_{6}$ as the major phase (>95\%); the crystallization also produced crystalline akermanite $\mathrm{Ca}_{2} \mathrm{MgSi}_{2} \mathrm{O}_{7}$, gehlenite $\mathrm{Ca}_{2} \mathrm{Al}_{2} \mathrm{SiO}_{7}$, and cristobalite $\mathrm{SiO}_{2}$ as the minor phase $(<2 \%)$.

The FTIR spectra of the glass samples heat-treated at 750 and $1000{ }^{\circ} \mathrm{C}$ are shown in Figure $2 \mathrm{~d}$ and 2e, respectively. After heat-treating at $750{ }^{\circ} \mathrm{C}$, the asymmetric $\mathrm{Si}-\mathrm{O}-\mathrm{Si}$ stretching vibration band shifted towards higher wave number with respect to the as-quenched glass, and the stretching peak observed was $1037 \mathrm{~cm}^{-1}$. It could be attributed to a crystallization process, i.e. liquid-liquid separation and metal cations depleting in the residual glassy phase ${ }^{10}$. However, this is not consistent with the DRX analysis, and it is attributed to the lower crystal nuclei content in the mass of the material $(<5 \%)$. On the other hand, it is evident that heat-treated at $1000{ }^{\circ} \mathrm{C}$ strongly altered the sample spectrum if it is compared to the spectrum presented in Figure 2c for the as-quenched glass sample. The asymmetric $\mathrm{Si}-\mathrm{O}-\mathrm{Si}$ stretching vibration band showed a positive shift towards higher wave-number with respect to the as-quenched glass, and the stretching peak observed was at $1076 \mathrm{~cm}^{-1}$. Moreover, peaks observed at 970, 885, 638, 520 , and $476 \mathrm{~cm}^{1}$ are due to crystalline phase formation.

It was found that both thermal treatment at 750 and $1000{ }^{\circ} \mathrm{C}$ did affect the mechanical strength. The Vickers microhardness value determined for the glass samples heat-treated at $750{ }^{\circ} \mathrm{C}$ was $773 \pm 26 \mathrm{HV}(\sim 7.6 \pm 0.3 \mathrm{GPa})$ : 
the mean value was $773 \mathrm{HV}$; the standard deviation was $19 \mathrm{HV}$; the $\mathrm{n}-1$ degrees of freedom of all tests were 4 . The value determined for the Vickers microhardness of the glass samples heat-treated at $1000{ }^{\circ} \mathrm{C}$ was $850 \pm 36 \mathrm{HV}$ $(\sim 8.3 \pm 0.4 \mathrm{GPa})$ : the mean value was $850 \mathrm{HV}$; the standard deviation was $26 \mathrm{HV}$; the $\mathrm{n}-1$ degrees of freedom of all tests were 4. According to Paul ${ }^{16}$, generally glass-ceramics are stronger than ordinary glasses. The obtained results indicate that both heat-treated products are in compliance with Paul's statement. Besides, the comparison between the results of Vickers microhardness obtained in this research for the heattreated products and the ceramic materials normally used in the civil construction revealed that they are quite similar ${ }^{17}$.

\section{Conclusions}

Based on this investigation the usefulness of vitrification technique was confirmed, since a homogeneous shiny dark brown-colored glass composed of 40.0 wt. (\%) of sandy tailing and 60 wt. (\%) of steelwork slag could be produced

\section{References}

1. Zarzycki J. Glasses and the vitreous state. Cambridge: University Press; 1991

2. Coruh S and Ergun ON. Leaching characteristics of copper flotation waste before and after vitrification. Journal of Environmental Management. 2006; 81:333-338. PMid:16730115. http://dx.doi.org/10.1016/j.jenvman.2005.11.006

3. Kavouras P, Komninou PH, Chrissafis K, Kaimakamis G, Kokkou S, Paraskevopoulos K et al. Microstructural changes of processed vitrified solid waste products. Journal of European Ceramic Society. 2003; 23:1305-1311. http://dx.doi. org/10.1016/S0955-2219(02)00289-3

4. Bernardo E, Varasso M, Cadamuro F and Hreglich S. Vitrification of wastes and preparation of chemically stable sintered glass-ceramic products. Journal of Non-Crystalline Solids. 2006; 352:4017-4023. http://dx.doi.org/10.1016/j. jnoncrysol.2006.07.001

5. Vogel W. Chemistry of glass. Westerville: The American Ceramic Society; 1985.

6. Francis AA. Conversion of blast furnace slag into new glass-ceramic material. Journal of European Ceramic Society. 2004; 24:2819-2824. http://dx.doi.org/10.1016/j. jeurceramsoc.2003.08.019

7. Francis AA. Crystallization kinetics of magnetic glass-ceramic prepared by the processing of waste materials. Materials Research Bulletin. 2006; 41:1146-1154. http://dx.doi. org/10.1016/j.materresbull.2005.11.002

8. Kim JM and Kim HS. Glass-ceramic produced from a municipal waste incinerator fly ash with high $\mathrm{Cl}$ content. Journal of European Ceramic Society. 2004; 24:2373-2382. http://dx.doi.org/10.1016/j.jeurceramsoc.2003.08.001

9. Kavouras P, Kehagias T, Tsilika I, Kaimakamis G, Chrissafis $\mathrm{K}$, Kokkou $\mathrm{S}$ et al. Glass-ceramic materials from electric by melting the batch mixture at $1400{ }^{\circ} \mathrm{C}$ for 1 hour. The crystallization heat-treatment process at $1000{ }^{\circ} \mathrm{C}$ for 2 hours could be used to produce glass-ceramics materials from sieved dry ball-milled powdered glass sample. It was also shown that an incipient crystallization occurred in the glass sample heat-treated at $750{ }^{\circ} \mathrm{C}$.

\section{Acknowledgements}

The authors gratefully acknowledge the financial support for this research from the Conselho Nacional de Desenvolvimento Científico e Tecnológico (CNPq) - National Counsel of Technological and Scientific Development - and Fundação de Amparo à Pesquisa do Estado de Minas Gerais (FAPEMIG) - Research Support Foundation of the State of Minas Gerais. The authors would like to thank the technical staff of CDTN/CNEN, particularly Dr. Ana Maria Matildes dos Santos, Dr. Wagner Reis da Costa Campos, Dr. Wilmar Barbosa Ferraz, and Geologist Walter de Brito for their valuable contributions.

arc furnace dust. Journal of Hazardous Materials A. 2007; 139:424-429. PMid:16716504. http://dx.doi.org/10.1016/j. jhazmat.2006.02.043

10. Pisciella P and Pelino M. FTIR Spectroscopy investigation of the crystallization process in an iron rich glass. Journal of European Ceramic Society. 2005; 25:1855-1861. http://dx.doi. org/10.1016/j.jeurceramsoc.2004.06.012

11. Ruan HD, Frost RL, Kloprogge JT and Duong L. Infrared spectroscopy of goethite dehydroxylation: III. FT-IR microscopy of in situ study of the thermal transformation of goethite to hematite. Spectrochimica Acta Part A. 2002; 58:967-981. http://dx.doi.org/10.1016/S1386-1425(01)00574-1

12. Argawal A, Davis KM and Tomozawa M. A simple IR spectroscopy method for determining fictive temperature of silica glasses. Journal of Non-Crystalline Solids. 1995; 185:191-198. http://dx.doi.org/10.1016/0022-3093(94)00676-8

13. Galeener FL. Band limits and the vibrational spectra of tetrahedral glasses. Physical Review B. 1979; 19:4292-4297. http://dx.doi.org/10.1103/PhysRevB.19.4292

14. Bell RJ, Bird NF and Dean P. Spectra of glasses: the effect of disorder upon frequency spectra. Journal of Physics C: Solid State Physics. 1974; 7:2457-2466. http://dx.doi. org/10.1088/0022-3719/7/14/010

15. Babisk MP. Desenvolvimento de vidros sodo-cálcicos a partir de resíduos de rochas ornamentais. [Dissertação]. Rio de Janeiro: Instituto Militar de Engenharia, 2009.

16. Paul A. Chemistry of glasses. London: Chapman and Hall; 1990.

17. Karamanov A and Pelino M. Evaluation of the degree of crystallization in glass-ceramics by density measurements. Journal of the European Ceramic Society. 1999; 19:649-654. http://dx.doi.org/10.1016/S0955-2219(98)00226-X 